Article

\title{
Monitoring the Forest Resources and Management of Private Landowners in Nagano, Japan*
}

\author{
Sándor F. Tóth ${ }^{* 1}$, Tatsuhito Ueki*2 and Marc E. McDill*3
}

\begin{abstract}
Approximately $80 \%$ of Japan's wood demand is currently met with imported wood. Although private forestry is the most important factor in domestic wood production, more and more private forest landowners have reduced their management activity, resulting in a general deterioration of the private plantation forests in Japan and heavy pressure on the forest resources of supplier countries. An integrated private forest management planning system is needed to reinvigorate private forestry in Japan. This research assessed the information management of forest owners' associations and some of the negative effects of parcelization on landowners' forest management activities. The research was done to provide answers to the question of how such an integrated private forest management system might be organized. We learned through questionnaires that the majority of the associations in Nagano Prefecture, who could be the foundation of an integrated management system, do not have the necessary information about their members' forest resources and management activity. Comprehensive directives are needed to establish standards for the associations on how to collect, maintain and update such information. On the other hand, the results of our investigation of forest landowners' behavior suggests that, without the right incentives for the landowners to implement cooperative forest management, an integrated planning system probably will not be successful. It appears that the current level of silvicultural activity and the proportion of owners having a management plan tend to be higher on larger forest properties. We also found that timber production was more likely to be a primary goal of ownership for owners of larger tracts. Cooperative forest management may provide a way to ameliorate the problem associated with small-scale ownerships and reduce the costs of management. Combined with more competitive prices, such cooperation could help Japanese private forestry reduce the country's reliance on imported timber.
\end{abstract}

Keywords: private forestry in Japan, parcelization, cross-boundary forest management, landowner attitudes, monitoring

\section{INTRODUCTION}

Japan is one of the largest wood consumers in the world. Because of its economic affluence and the liberalization of its timber-trade in the early 1960s, Japan has become a strong timber importing country (NOMURA, 1978; MURASHIMA, 1997;
Yoshimoto et al., 1998; NAGASHIMA et al., 1999). Due to soaring forest management and labor costs, domestic wood production has not been able to compete against foreign timber industries (YuKuTAKE et al., 1998). The principal reasons for the high costs are an expensive and scarce labor force, difficult terrain, and small-scale, fragmented ownerships. It is no wonder that the last three decades have witnessed a gradual stagnation of

\footnotetext{
* This Communication was presented at the XII World Forestry Congress in September 2003 in Quebec City, Canada

${ }^{* 1}$ Research Associate, School of Forest Resources, College of Agricultural Sciences, The Pennsylvania State University, 214B Ferguson Building, University Park, PA 16802-4301
}

\footnotetext{
${ }^{* 2}$ Professor at Shinshu University, Faculty of Agriculture, Department of Forest Science, 8304 Minamiminowa, Kamiina, Nagano 399-4598, Japan

${ }^{* 3}$ Associate Professor, School of Forest Resources, College of Agricultural Sciences, The Pennsylvania State University, 214B Ferguson Building, University Park, PA 16802-4301
} 
domestic private forestry - the most important factor in wood production in the country (private forests currently account for $74 \%$ of the forest products produced in Japan). As a result of the lower level of silvicultural treatments, the general condition of private forest resources - mostly plantation forests - has been deteriorating.

However, the sluggish domestic forest industry is only one of the negative outcomes of Japan's low self-sufficiency rate in timber production. Currently, roughly $80 \%$ of the country's total wood demand is supplied by import timber (approx. 90 million $\mathrm{m}^{3}$ annually), $41 \%$ of which comes from Canada and the U.S., $22 \%$ from Russia, 18\% from South-Pacific Asia, 9\% from New Zealand, and 10\% from other sources (Ministry of Agriculture, Forestry and Fisheries 2000). Furthermore, the forest resources of many supplier countries are under severe harvesting pressure. Forest overexploitation had forced the Philippines (in the late 1960s), Indonesia (in 1985), Sabah (in 1993) and Sarawak (in 1995) to ban their log exports completely (TACHIBANA, 2000).

If domestic timber prices were competitive, the current annual increment of plantation forests (91 million $\mathrm{m}^{3}$ in 1995), $65 \%$ of which are private, could satisfy a significantly larger share of its demand for wood. Japan must revitalize its private forestry. Doing so would, on the one hand, solve the problem of untended plantation forests, and it would also relieve the supplier countries of the burden on their own forest resources. Revitalizing private forestry would, in addition, provide job opportunities for people wishing to live and work in the countryside and, at the same time, contribute to efforts to stop, or at least decelerate, the dispiriting process by which rural Japan is becoming depopulated.

What can be done to increase Japan's self-sufficiency rate in timber production? As the parcelization of private forestland is one of the major factors that contribute to high management costs, we believe an integrated forest management planning system that would promote cooperative forest management could be effective in increasing the profitability of domestic timber production. The already existing forest owners' associations (FOA) could be the foundation of such a system. There are three reasons why they would be well suited for this role: 1) most private forest owners are members of the FOAs (70-75\% in terms of forest area); 2) the FOAs have the most direct relationship with the landowners (Fig. 1); and 3) the FOAs were legally established, by government initiatives, with this purpose in mind throughout the country.

The present paper analyzes whether the forest owners' associations are in possession of the information about their member owners' forest resources and management activity that would be essential to implement integrated forest management planning. We researched what data are available and what additional information needs to be collected in the future. The second part of the paper addresses the parcelization problem. The investigation focused on the relationship between the size of forestland and the attitudes of landowners in relation to forest management issues, such as management activity, having a forest management plan, and ownership objectives.

\section{METHODS}

\section{FOA Survey}

One objective of this study was to assess the amount, type and currency of the information held by the FOAs regarding their members and their activities. The first phase of this research focused on the 33 FOAs in Nagano Prefecture in 2001. The scope of administration of these FOAs ranged from 793ha to 64,721 ha. The overall forest area administered by the FOAs totals 507,984 ha, of which 367,353 ha $(72 \%)$ are owned privately and 140,631 ha $(28 \%)$ is public property (e.g., municipal and property ward forests). The 367,353 ha of private forests under the administration of the FOAs is $72 \%$ of the total area of private forests in Nagano Prefecture (512,903ha). Given their legal role in private forestry, one would expect the associations to have up-to-date, reliable information on the forest resources and silvicultural activities of their members.

In order to assess the FOAs' information management, we sent a questionnaire to each of the associations in the prefecture. The FOAs were asked whether they had the following data: 1) the names, addresses, and type of forest ownership (independent, communal, etc.) of their members; 2) the location of their members' forestland; 3 ) the acreage (area) of forestland owned by each member; 4) the area of artificial and natural forests; 5) the growing stock on artificial and natural forests; 6) the distribution of area by the primary tree species; 7) the distribution of growing stock by the primary tree species; 8) the age-class distribution by area; 9) the ageclass distribution by volume for the primary tree species; and 10) records of silvicultural operations. We considered this information to be the minimal prerequisite for effective management planning. The FOAs were also requested to clarify whether the data were available for individual members or only as a total for their entire administrative area.

\section{Landowner Survey}

In order to address the problem of forest management inactivity, charting the attitudes, needs and constraints of landowners is essential. We administered a second questionnaire with the objective of obtaining the following information from the landowners: 1$)$ land ownership size category ( $<5$ ha; 5 10ha; 10-20ha; $>20 \mathrm{ha}$ ); 2) the number of silvicultural operations that were carried out in the last 5 years; 3 ) whether they have a forest management plan or not; and 4) forestland ownership objectives. A basic question was whether the size of a forestland ownership affects silvicultural activities, planning, or ownership objectives.

The private, individual owners who are members of Kami 
Ina Forest Owners' Association (Kami Ina FOA) were the target population of this questionnaire. The total area of forestland owned by the members of the association is $57,332 \mathrm{ha}$, of which $45,947 \mathrm{ha}$ are owned by individual private forest landowners. This represents $87 \%$ of all private forests in the district. There are 16,522 private forest landowners in Kami Ina Administrative District, of which 12,772 (77\%) are members of the FOA. Information (address, location of forest property etc.) concerning non-members was not available. Contact information for member owners (address, telephone number, forest area etc) was obtained from Kami Ina FOA's files.

A mailed questionnaire, followed by postcard reminders, was used to collect the data. The questionnaires were sent to all of the owners with at least 20 ha of forestland (there were 87 of them), to 100 owners with $0-5$ ha, to 102 owners with $5-10$ ha, and to 107 owners with 10-20ha of forestland. Attention was paid to maintaining the geographical distribution of the landowners chosen in the district. Because the number of owners in each category was roughly the same, the proportion in the total number of owners represented in the sample is different in each group. The data were stratified because information and statistics concerning Japanese private forestry are usually reported in this four forestland-size category format. The response rates in the four property size categories of $0-5$ ha, $5-10$ ha, $10-20$ ha, and $>20$ ha were $41.7 \%, 52.5 \%, 55.3 \%$ and $55.5 \%$, respectively.

The survey instrument included the following questions: 1) How many of each of the main silvicultural operations (afforestation, weeding, pruning, clearing, improvement thinning, commercial thinning and final cutting) have you carried out during the last 5 years (1996-2001)? 2) Do you have a forest management plan? 3) Why did you choose to own forestland (A: Timber production; B: Charcoal, Shiitake-, Matsutake-mushroom or other secondary forest products; C: Recreation, sport, tourism, etc.; C: Inherited land, no specific reason for ownership; D: Other reasons)? Evidence was sought to test the following hypotheses.

1) The level of silvicultural activity tends to be higher on larger forest lots.

2) The likelihood that owners have a management plan is greater for the larger tracts than for the smaller ones.

3) Timber production is more likely to be the main goal of ownership for larger forest ownerships than for the smaller ones.

Two-sample t-tests were run for each combination of forestland size categories ('0-5ha' vs. '5-10ha', '5-10ha' vs. ' 10 20ha', etc) to test the first hypothesis (MINITAB Statistical Software, 1999). A Mantel-Haenszel Chi-square test was used to determine whether or not having a management plan depends on the size of forestland parcel (SAS, 1989). To test the third hypothesis, 95\% confidence intervals were calculated for the cells corresponding to each response category.

\section{RESULTS}

Twenty-three associations (70\%) completed the FOA questionnaire. Four FOAs had all ten sets of data in hand. By contrast, one FOA did not even have basic information on the name, address, and type of ownership of its members. More than half of the associations maintain the first 5 categories of data at the owner level and the first 8 categories of data at the level of their total administrative area. Area and volume data broken down by main tree species and age-classes at the owners' level are only available for one third of the associations. Only $43 \%$ of the associations maintain data regarding the silvicultural operations implemented in their member owners' forests.

The responses to the three questions are summarized in Table 1, 2, and 3, respectively. Tests regarding the hypotheses addressed by the second questionnaire provided the following results. The average number of silvicultural operations was significantly higher in the '5-10ha' and the '10-20ha' groups than in the '0-5ha' group (the P-values in these comparisons were 0.015 and 0.024 , respectively). The difference between the 'Over 20ha' and '0-5ha' groups was significant only at the 0.084 level. For the three larger ownership classes, the smallest class, 5-10ha, had the most actions per ownership and the largest class had the lowest. However, none of these differences were statistically significant (Table 1). The results of the Mantel-Haenszel test indicated that there is a positive

Table 1 Forest management activity

\begin{tabular}{lcccc}
\hline \multirow{2}{*}{ Type of action } & \multicolumn{4}{c}{ Number of actions } \\
\cline { 2 - 5 } & $\mathbf{0 - 5 h a}$ & $\mathbf{5 - 1 0 h a}$ & $\mathbf{1 0 - 2 0 h a}$ & Over 20ha \\
\hline Afforestation, planting & 9 & 23 & 23 & 16 \\
Weeding & 20 & 31 & 31 & 18 \\
Pruning & 24 & 34 & 36 & 28 \\
Clearing & 15 & 30 & 35 & 24 \\
Improvement thinning & 11 & 26 & 35 & 24 \\
Commercial thimming & 8 & 18 & 18 & 11 \\
Final cutting & 5 & $\mathbf{1 0}$ & 5 & 5 \\
Total & $\mathbf{9 2}$ & $\mathbf{1 7 2}$ & $\mathbf{1 8 3}$ & $\mathbf{1 2 6}$ \\
\hline Average \# of actions & $\mathbf{2 . 3 0}$ & $\mathbf{3 . 3 1}$ & $\mathbf{3 . 2 1}$ & $\mathbf{3 . 0 0}$ \\
\hline Number of ownerships & 40 & 52 & 57 & 42 \\
\hline
\end{tabular}

Table 2 Forestry based on forest management plans

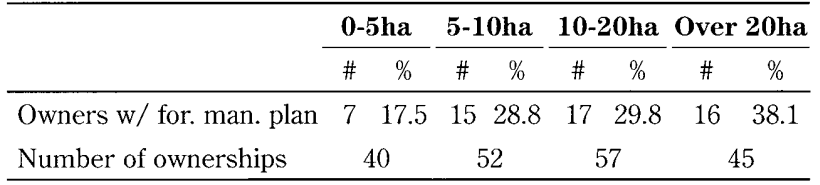


Table 3 Aim of forest ownership

\begin{tabular}{|c|c|c|c|c|c|c|c|c|}
\hline & \multicolumn{2}{|c|}{ 0-5ha } & \multicolumn{2}{|c|}{ 5-10ha } & \multicolumn{2}{|c|}{ 10-20ha } & \multicolumn{2}{|c|}{ Over 20ha } \\
\hline & $\#$ & $\%$ & $\#$ & $\%$ & $\#$ & $\%$ & $\#$ & $\%$ \\
\hline \multirow{2}{*}{ Timber production } & 12 & 30.0 & 27 & 51.9 & 39 & 68.4 & 27 & 60.0 \\
\hline & \multicolumn{2}{|c|}{ C.I. $(15.8,44.2)$} & \multicolumn{2}{|c|}{ C.I. $(38.3,65.5)$} & \multicolumn{2}{|c|}{ C.I. $(56.3,80.5)$} & \multicolumn{2}{|c|}{ C.I. $(45.7,74.3)$} \\
\hline Charcoal, Shiitake, etc. & 10 & 25.0 & 20 & 38.5 & 29 & 50.9 & 19 & 42.2 \\
\hline Recreation & 3 & 7.5 & 3 & 5.8 & 2 & 3.5 & 3 & 6.7 \\
\hline \multirow{2}{*}{$\begin{array}{l}\text { Inherited land, no specific } \\
\text { reason for ownership }\end{array}$} & 25 & 62.5 & 29 & 55.8 & 20 & 35.1 & 13 & 28.9 \\
\hline & \multicolumn{2}{|c|}{ C.I. $(47.5,77.5)$} & \multicolumn{2}{|c|}{ C.I. $(42.3,69.3)$} & \multicolumn{2}{|c|}{ C.I. $(22.7,47.5)$} & \multicolumn{2}{|c|}{ C.I. $(15.7,42.1$} \\
\hline Other reasons & 2 & 5.0 & 5 & 9.6 & 1 & 1.8 & 1 & 2.2 \\
\hline Number of ownerships & \multicolumn{2}{|c|}{40} & \multicolumn{2}{|c|}{52} & \multicolumn{2}{|c|}{57} & \multicolumn{2}{|c|}{45} \\
\hline
\end{tabular}

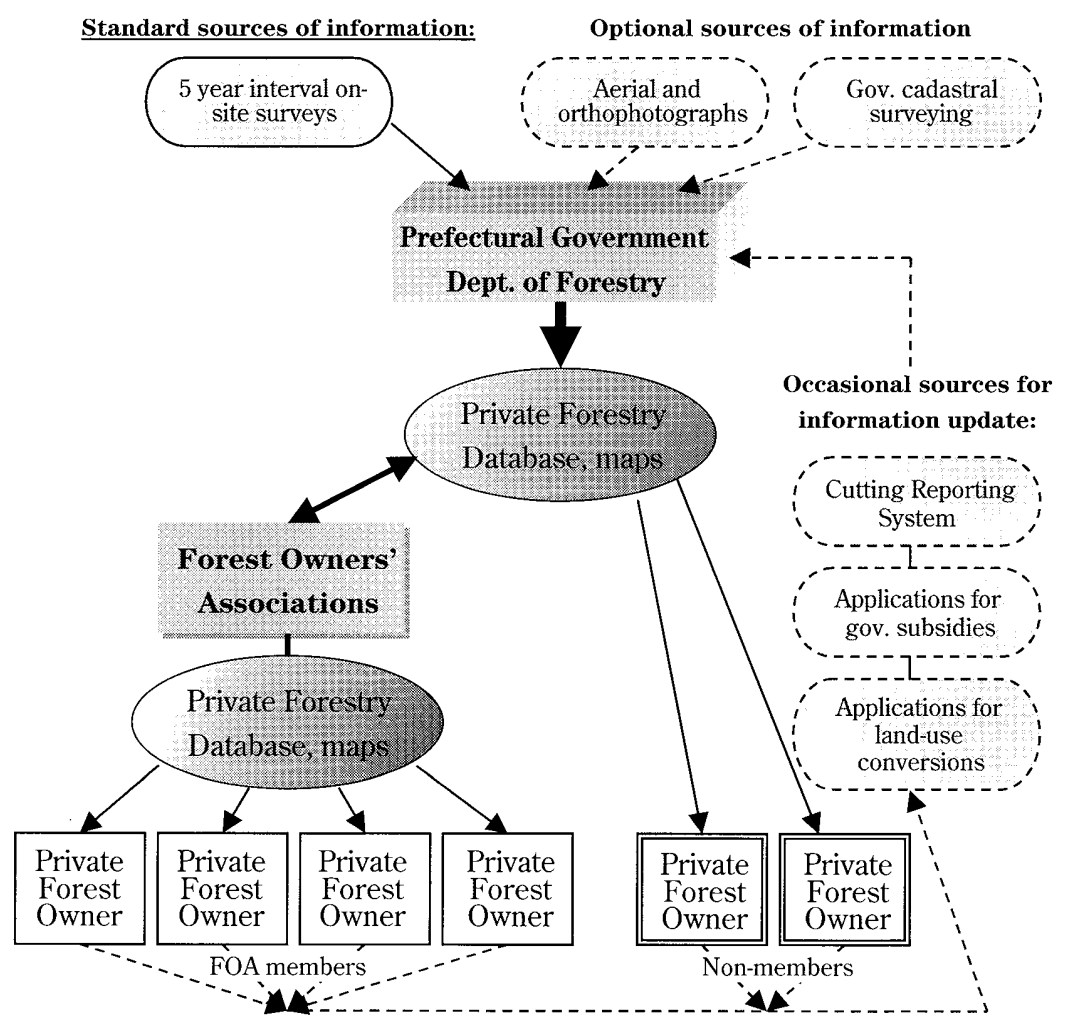

Fig. 1 Information flow in private forests in Japan

relationship between the size of forest property and having a management plan only at the $8 \%$ level of significance (Table 2). As for the primary objectives of forestland ownership, Timber production' was cited significantly more often in the '10-20ha' and 'over 20ha' categories than in the ' $0-5$ ha' category. The difference between the '5-10ha' ownerships and the other three categories was not significant at the 0.05 level, however. For 'Inherited land...', significant differences were found between the ' $0-5$ ha' size class and the larger two categories, and between the ' 5 -10ha' and the 'Over 20ha' size classes (Table 3).

\section{DISCUSSION}

The results of the FOA survey imply that there is apparently no consistency in the information management of the associations. This is in spite of the fact that the Department of Forestry (Prefectural Government) theoretically provides each association with a private forestry database (updated by field surveys in every 5 years), accompanied by maps indicating the forest ownerships. One must assume that the quality of the data is dependent upon the FOAs' individual 
policies. It seems that there are no common guidelines or fixed criteria for the FOAs' data policies, even within the prefecture. Obviously, this makes it extremely difficult to monitor the ongoing processes in the private sector's forest resources and forest management activity.

Fig. 1 may provide some additional hints of why the FOAs' information management is so ineffective. Although the Prefectural Government is supposed to provide the forest owners' associations with inventory and ownership data and the landowners themselves may also acquire this information from them, there is no regular feedback from the grassroots level in relation to the accuracy of information or the changes that took place on the owners' lands in the meantime. The majority of the landowners are not even aware of the existence of the database (Matsushita, 1996). The optional cutting reports and the applications for government subsidies and land-use conversions may provide useful but only occasional information.

Good information management is a necessary but not sufficient condition for reinvigorating the private forestry sector in Japan. The results of our investigation regarding forest landowners' behavior may provide some clues why the promotion of cooperative management must also be incorporated into an integrated forest management planning system. The results indicate that the level of silvicultural activity and the probability of having a management plan tend to be higher on larger forest properties. The results also indicate that the role of timber production as an ownership objective was significantly greater in the larger tracts than in the smaller ones. Obviously, tendencies of forest ownership parcelization do not favor domestic timber production in Japan. Using the same forest roads, machinery, management plan and administrative procedures (such as the applications for government subsidies) would significantly reduce management costs. This is, however, not the only benefit of cooperative forest management. Since a larger forest area usually has a better age-class distribution than a smaller one, and, in general, there tends to be a higher diversity of assets in a larger area, cooperative management may provide landowners with a more balanced and diverse flux of timber or other forest products. This may serve as an incentive for the landowners to think about their forestland as a potential and reliable source of income.

\section{CONCLUSION}

Monitoring the forest resources and forestry activities on private forests is a prerequisite for finding effective measures for integrating, orienting and reinvigorating the sector's role in supplying the Japanese population with the various forest products they demand. Forest owners' associations could act as the principal organizations to fulfill these tasks. However, considering the above results regarding the FOAs' data management policies, radical changes would be needed for them to fulfill this role. Comprehensive directives or guidelines should be established to encourage the associations to collect, maintain, update and utilize the information that would be minimally necessary for management planning at both the regional and at the owners' level. It is the responsibility of the prefectural governments to determine the quality of the information required to enable effective management planning.

In summary, we propose the following action plan: Step 1 is to construct a practical monitoring and information management system for private forests. Step 2 would address the parcelization problem by promoting cooperative management by the FOAs, in collaboration with the prefectural and municipal forestry offices. Finally, Step 3 requires a radical change in the government's incentive policies in order to realize the above "movements." Without adequate subsidies of silvicultural operations, cooperative management, and preparation of management plans, the landowners will not be encouraged to act, as the stagnant domestic wood-market currently does not provide them with sufficient profits to cover management costs.

There are many other timber importing countries like Japan where a substantial portion of timberland is held by inactive, small-scale private ownerships. South Korea, the United States, and to a lesser extent, Spain, Italy, France and Germany all share the same situation. The relatively low selfsufficiency rate of these countries in timber production might be increased by directing attention to those owners who have, or might have, the intention but, due to their small scale, lack the resources to manage their forests for timber production. Cooperative forest management is an important option for overcoming this problem. The potential of this segment of landowners can only be evaluated and capitalized on by maintaining a permanent and comprehensive monitoring system that not only keeps track of these forest resources but also charts the current needs and constraints of the landowners. Although the establishment and maintenance costs of such a system might be high, these developed countries are the ones that should take the lead in developing landscape-level, cross-boundary forest management schemes. Success in these efforts will reduce the burden these countries place on the resources of the timber supplier countries. We are not suggesting the eradication of the international timber trade. However, by achieving a more balanced import ratio in these countries, the suppliers could focus on a more sustainable level of production of higher quality forest products.

\section{LITERATURE CITED}

MatsushitA, K., (1996): An Analysis of the Recent Situation and Problems in the Cutting Reporting System. Journal of Forest Planning 2(2): 67-75

Ministry of Agriculture, (2000): Statistical Handbook of Forestry. 
Forestry Agency, Ministry of Agriculture, Forestry and Fisheries, Tokyo, Japan

Minitab INC., (1999): Statistical Software Manual. Minitab Inc., http://www.Minitab.com

Murashima, Y., (1997): Management of Private Forests and Sustainable Forestry in Japan. Proceedings of IUFRO Symposium in Kyoto 1997: Sustainable Management of Small Scale Forestry. pp. $12-17$

Nagashima, K. and NaKagoshi, N., (1999): Potential Utilization of New Zealand Wood in Japan. Journal of Forest Planning 5(2): 57-63 Nomura, I., (1978): Shingaizaidokuhon. Ringyoshinbunsha, Tokyo, Japan. 419 pp.

SAS InSTITUTE, INC., (2000): SAS/STAT User's Guide, Version 8, Volumes 1, 2, and 3. SAS Institute, Inc., Cary, NC. 3,884 pp.

TACHibanA, S., (2000): Impacts of Log Export Restrictions in
Southeast Asia on the Japanese Plywood Market: An Econometric Analysis. Journal of Forest Research, The Japanese Forestry Society $5(2)$

Yoshimoto, A., Kaitta, J. and Yukutake, K., (1998): Japanese Forest Sector Modeling - Possibility of Increasing Domestic Timber Production. Proceedings of International Symposium on Global Concerns for Forest Resource Utilization - Sustainable Use and Management. Miyazaki, Japan. p. 459-469

Yukutake, K. and Yoshimoto, A., (1998): Current States of Japanese Forestry and Timber Trade. Proceedings of International Symposium on Global Concerns for Forest Resource Utilization Sustainable Use and Management. Miyazaki, Japan p. 28-38

(Received 24 July 2006) (Accepted 5 October 2006) 